\title{
Social determinants of health in the Mixtec and Zapotec community in Ventura County, California
}

\author{
Annette E Maxwell ${ }^{1 *}$, Sandra Young ${ }^{2}$, Catherine M Crespi ${ }^{1}$, Roena Rabelo Vega', Reggie T Cayetano ${ }^{1}$ \\ and Roshan Bastani ${ }^{1}$
}

\begin{abstract}
Introduction: There are an estimated 165,000 indigenous Mexicans living in California, including Mixtec and Zapotec immigrant farm workers. Because many of these immigrants speak only their native non-written languages, there is little information about the needs of this community. An academic-community partnership research team developed a survey to assess basic needs that are known to be social determinants of health in the Mixtec and Zapotec community in Ventura County.

Methods: In summer 2013, Spanish-Mixteco and Spanish-Zapoteco bilingual promotoras conducted surveys in Spanish, Mixteco and Zapoteco in the greater Oxnard area in Ventura County, California to assess the following basic needs: ability of adults and children to obtain health services; household needs regarding work opportunities, food, housing, transportation, safety and education; and discrimination. Independent variables included respondent characteristics such as age, gender, marital status, living part of the year in another city, and household characteristics such as Spanish spoken in the household, number of household members and number of health care providers/ agencies used. Several sets of analyses examined the relationship between basic needs and independent variables.

Results: Respondents ( $N=989)$ reported insufficient employment opportunities $(74 \%)$, food for the family (59\%) or housing (48\%), lack of transportation (59\%), and discrimination or bullying (34\%). Most reported access to medical care for children (90\%), but only 57\% of respondents were able to get health care for themselves.

Conclusions: Many basic needs in the Mixtec and Zapotec community in Ventura County are unmet. It will require many different resources and services to address the needs of this community and to overcome longstanding inequities that are experienced by immigrant farm workers. Our findings will guide the development of future health programs and will serve as a baseline to evaluate the impact of services to improve the health conditions in this community.
\end{abstract}

Keywords: Household survey, Indigenous farm workers, Community-engaged research, Promotoras, Social determinants of health

\section{Introduction}

There are an estimated 165,000 indigenous Mexicans living in California [1]. Many are farm workers, a group that has historically been exploited as a cheap source of labor [2]. Few studies have focused on indigenous communities in Mexico [3-6] or in the United States [7-11].

\footnotetext{
* Correspondence: amaxwell@ucla.edu

${ }^{1}$ Fielding School of Public Health and Jonsson Comprehensive Cancer Center, UCLA Kaiser Permanente Center for Health Equity, University of California, 650 Charles Young Drive South, A2-125 CHS, Box 956900, Los Angeles, CA 90095-6900, USA

Full list of author information is available at the end of the article
}

Mixtecs and Zapotecs, two indigenous groups from the Oaxaca area in Mexico, have settled in large numbers in Ventura County, California, and many are employed as farm workers with little pay and only seasonal work. Research in these and other immigrant communities is challenging due to language barriers, lack of trust, long working hours, and fear of deportation among some members of the community [7]. While some Mixtecs and Zapotecs speak Spanish and/or English, others speak only their native languages, Mixteco or Zapoteco, which are oral, not written languages. This poses additional challenges for 
survey research. Consequently, data on the demographic characteristics of this community and its needs are lacking.

The Mixteco/Indigena Community Organizing Project (MICOP), a nonprofit organization, and the University of California Los Angeles Fielding School of Public Health partnered to conduct a community assessment that would provide local data regarding the needs of the Mixtec and Zapotec community. Both partners planned the study, applied for funding, agreed on scope of work and budgets, and worked closely together throughout the whole study, including data analysis and interpretation. Following principles of community-based participatory research $[12,13]$, the partners decided to focus on assessing basic needs that are known to be social determinants of health, including employment, food security, housing, access to health care, transportation, safety and discrimination. The health impact pyramid framework postulates that addressing these basic needs has the greatest potential to improve health [14]. The purpose of this paper is to describe the results of community-based participatory research in which indigenous promotoras conducted a large-scale needs assessment.

\section{Methods}

Development of survey instrument in English, Spanish and indigenous languages

MICOP, UCLA and a Mixtec Advisory Board worked together to develop a survey that assessed the following basic needs: ability of adults and children to obtain health services; household needs regarding work opportunities, food, housing, transportation, safety and education; and discrimination. Because of the need to keep the survey short and simple, these constructs were not further explained. Participants were simply asked if they or someone in their household had experienced problems in these areas and responses were recorded mostly using simple yes/no checklists. We also assessed demographic information on respondents and household information including composition and use of local agencies and health service providers.

The first English language draft of the survey was translated into Spanish for discussion with non-English speaking promotoras and other community members. Modifications were made parallel in the English and the Spanish versions to simplify and clarify questions. After the Spanish language survey was finalized, a small group of bilingual Mixteco and Spanish speaking promotoras audio-recorded a Mixteco version of the survey, which was provided to all promotoras for practicing, to ensure consistency in the administration in the Mixteco language. This standardization was not necessary for the Zapoteco version, because a single promotora administered all Zapoteco surveys.

\section{Training of promotoras}

MICOP identified 8 Mixteco/Spanish and one Zapoteco/ Spanish speaking promotoras, who attended a 6 hour training session in Spanish. The training agenda included purpose of the study, principles of research including voluntary participation and confidentiality, recruitment of participants, how to obtain informed consent, the interviewing process and interview role playing. At a follow-up training/debriefing, promotoras stated that almost all of the people they asked were willing to participate; only a total of 10-12 people they approached refused to be interviewed. Reason for refusal was not collected. Promotoras received a stipend for attending the training and for conducting interviews.

\section{Administration of survey instrument}

Working in pairs, promotoras conducted community survey in Spanish, Mixteco and Zapoteco in Oxnard, Port Hueneme and El Rio between May and September 2013. Promotoras explained that this survey was done to learn about health needs in the Mixtec and Zapotec community and obtained oral consent prior to administering the survey. They conducted the majority of surveys going door to door (37\%), at parks (53\%), and at a school (5\%), during the week (86\%) and on weekends (14\%), and noted responses on the Spanish language surveys. Surveys were conducted anonymously on the advice of the Mixtec Advisory Board that feared that many community members would not participate if they had to give their name. The budget for this study did not allow payment of participants. Instead and based on community suggestions, participants received an accordion plastic folder for document storage as a token of appreciation. All project activities were approved by the Institutional Review Board of the University of California, Los Angeles.

\section{Measures}

Seven of the basic needs items were asked as yes/no questions, e.g., "Is your housing situation sufficient for your needs?" The following three items had 3 possible responses: "Are you able to get to the places you need to go?" - yes/no/only to some places; "Are you able to work enough of the year to support your family?" - yes/ no/yes, but I am struggling; "Does your family have enough food to eat?" - yes/no/sometimes. All 10 items were dichotomized as basic need met ("yes" response) versus not met (other response). Two questions on discrimination were reverse coded, e.g., "Have you experienced discrimination or bullying?"

Respondents were also asked if they had used the services of 12 local agencies and health service providers and were shown the logos of these providers to aid in recall. 


\section{Analysis}

Descriptive statistics are provided for respondent characteristics. Associations among the 10 basic needs items were assessed using Yule's Q (equivalent to the gamma statistic for two binary variables) and chi-square tests. Guidelines for interpreting the absolute value of Yule's $\mathrm{Q}$ are: 0 to .24, virtually no relationship; 25 to .49 , weak relationship; .50 to .74 , moderate relationship; .75 to 1.0 , strong relationship [15]. Several sets of analyses examined the relationship between basic needs and independent variables. The independent variables included gender, marital status (married/living together versus other), living part of the year in another city (yes/no), Spanish spoken in the household (yes/no), age of respondent $(<30$ years versus $\geq 30$ years), number of household members ( $<5$ versus $\geq 5$ ) and number of health care providers/agencies used ( $>6$ versus $\leq 6$ ). The last three variables were dichotomized at their medians. Chi-square tests were used to examine the bivariate relationship between each basic need and each independent variable. In addition, for each respondent, we computed a total needs met score by summing the number of basic needs met, and used this score as the dependent variable in t tests. Each of the 10 basic needs measures were also used as dependent variables in multivariate logistic regression models including all independent variables.

\section{Results}

A total of 989 respondents completed the survey. As shown in Table 1, respondents were predominantly female, married or living together and all were born in Mexico. The average age of respondents was 31 years. Household size averaged 4.9 members. Languages spoken at home included Spanish and Mixteco (54\%), Mixteco only (23\%), Spanish and Zapoteco (8\%), Spanish only (8\%), and English and at least one other language (7\%).

Figure 1 shows overall levels of basic needs. Only 26\% of respondents reported that they were able to work enough of the year to support their family and $41 \%$ reported that their family had enough food. Only 52\% of respondents reported sufficient housing, 57\% reported having access to health care, $41 \%$ reported access to transportation, 50\% reported neighborhood safety and $58 \%$ reported education opportunities. Eighty-six percent of respondents stated that they were treated with respect by employers, but $34 \%$ had experienced discrimination or bullying and $27 \%$ reported that another household member had experienced discrimination or bullying. Twenty five percent of the sample had only 3 basic needs met out of the 10 that were assessed and $22 \%$ of the sample had 8 or more needs met. Most households included children (90\%, data not shown) and the majority of respondents of those households reported access to medical care for children (90\%), being able to support children's success in school (89\%) and having childcare/ early education opportunities available for their family (76\%).

Table 2 shows moderate $(\mathrm{Q}=.50$ to .74$)$ to strong $(\mathrm{Q} \geq .75)$ relationships among employment opportunities, food security, housing condition sufficiency, healthcare access and transportation access. Weaker relationships are found among indicators of neighborhood safety, employer respect and discrimination, and between these measures and the first group of variables. Education opportunities showed little relationship with the other measures.

Table 3 reports the results investigating how respondent characteristics are associated with basic needs. The total number of basic needs met was higher among male respondents than among females; differences in employment and education opportunities and transportation access accounted for much of this difference. Married respondents reported more needs met than single respondents, with greater healthcare access and employment opportunities contributing to the higher scores. Respondents under 30 years of age reported more needs met than older respondents for most (7 out of 10) basic needs. Similarly, smaller households reported significantly more needs met than larger households, with higher rates of needs met for food security, housing sufficiency, healthcare access, and freedom from discrimination. Respondents who had used more than 6 health and social services also reported more needs met. Respondents who had spent time in another city reported better healthcare access, while those who spoke Spanish reported lower housing sufficiency and healthcare access but better education opportunities and employer respect.

Table 4 presents adjusted odds ratios for the association of each predictor with each basic needs measure. Associations were similar to those found in the unadjusted analyses, with some notable differences. Males were significantly more likely than females to report sufficient employment opportunities, food security, access to transportation and education opportunities. Respondents who were married or living as married were more likely than single respondents to report basic needs covered for five of the ten needs assessed. Respondents from Spanish speaking households were more likely to report sufficient education opportunities and being treated with respect by employers than respondents from non-Spanish speaking households, but they were less likely to report sufficient housing and having access to healthcare for themselves. When adjusting for other characteristics, age was no longer a significant factor for most needs; only sufficient housing and no discrimination were met with higher odds than for older respondents. Respondents from smaller households (less than 5 household members) were more likely to report food security, sufficient housing and access to healthcare and transportation than respondents 
Table 1 Demographic characteristics of survey respondents $(N=989)$, Ventura County, California, 2013

\begin{tabular}{|c|c|c|c|}
\hline Characteristics & $\mathrm{N}^{*}$ & & $\%$ \\
\hline Female & $834 / 988$ & & 84 \\
\hline Married/living as married & $847 / 970$ & & 87 \\
\hline Has lived at same address for 12 months & 791/984 & & 80 \\
\hline Spent part of the year in another city & $144 / 961$ & & 15 \\
\hline \multicolumn{4}{|l|}{ Place of birth } \\
\hline Oaxaca & $818 / 966$ & & 85 \\
\hline Guerrero/other & $148 / 966$ & & 15 \\
\hline Has at least one child living in Mexico & $294 / 969$ & & 30 \\
\hline \multicolumn{4}{|l|}{ Languages spoken at home } \\
\hline Spanish \& Mixteco & $524 / 972$ & & 54 \\
\hline Mixteco only & $224 / 972$ & & 23 \\
\hline Spanish \& Zapotec & $79 / 972$ & & 8 \\
\hline Spanish only & $77 / 972$ & & 8 \\
\hline English \& another language & $64 / 972$ & & 7 \\
\hline Other language combinations & 4/972 & & 0.4 \\
\hline \multirow[t]{2}{*}{ Heard of MICOP prior to survey } & $726 / 963$ & & 75 \\
\hline & Mean (Range) & Median & SD \\
\hline Age of respondent & $31.2(18-86)$ & 30 & 9.4 \\
\hline Number of adults in household & $2.2(1-10)$ & 2 & 0.9 \\
\hline Number of children in household & $2.7(0-10)$ & 3 & 1.6 \\
\hline Total number of household members & $4.9(1-13)$ & 5 & 1.9 \\
\hline Number of healthcare agencies/services used & $6.0(0-12)$ & 6 & 2.5 \\
\hline
\end{tabular}

*Denominators vary due to missing responses.

MICOP = Mixteco/Indigena Community Organizing Project.

Able to work enough of the year to support family (Employment opportunities)

Family has enough food to eat (Food security)

Housing situation sufficient for needs (Housing situation sufficiency)

Able to get health care for him/herself (Healthcare access)

Able to get to places they need to go, such as school, clinic, park, social agencies (Transportation access)

Feels safe to walk around in their neighborhood (Neighborhood safety)

Has opportunity to further own education (Education opportunities)

Treated with respect by employer (Employer respect)

Respondent has NOT experienced discrimination or bullying (No discrimination against respondent)

A household member has NOT experienced discrimination or bullying (No discrimination against household member)

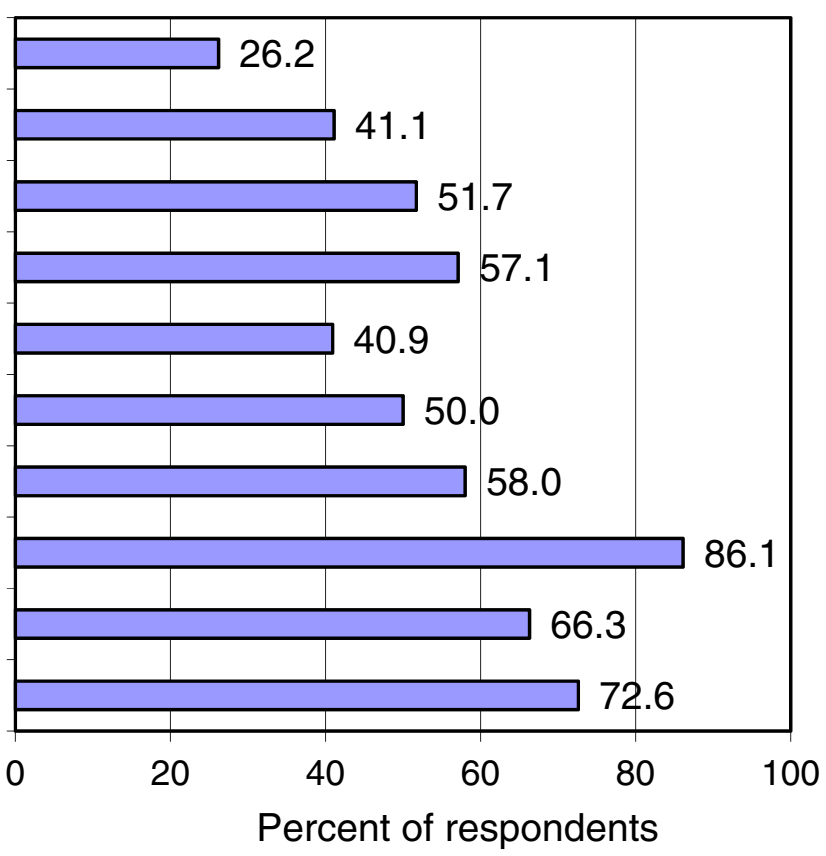

Figure 1 Coverage of basic needs among respondents. 
Table 2 Associations among basic needs in the Mixtec/Zapotec community in Ventura County, California, 2013 ( $N=989$ )

\begin{tabular}{|c|c|c|c|c|c|c|c|c|c|c|}
\hline \multirow[t]{2}{*}{ Basic needs items } & \multicolumn{10}{|l|}{ Yule's Q } \\
\hline & $\begin{array}{l}\text { Employment } \\
\text { opportunities }\end{array}$ & $\begin{array}{l}\text { Food } \\
\text { security }\end{array}$ & $\begin{array}{l}\text { Housing condition } \\
\text { sufficiency }\end{array}$ & $\begin{array}{l}\text { Healthcare } \\
\text { access }\end{array}$ & $\begin{array}{l}\text { Transportation } \\
\text { access }\end{array}$ & $\begin{array}{l}\text { Neighborhood } \\
\text { safety }\end{array}$ & $\begin{array}{l}\text { Education } \\
\text { opportunities }\end{array}$ & $\begin{array}{l}\text { Employer } \\
\text { respect }\end{array}$ & $\begin{array}{l}\text { No discrimination } \\
\text { of respondent }\end{array}$ & $\begin{array}{l}\text { No discrimination of } \\
\text { household member/s }\end{array}$ \\
\hline Employment opportunities & 1 & $.82^{*}$ & $.60^{*}$ & $.68^{*}$ & $.82^{*}$ & $.55^{*}$ & .12 & $.48^{*}$ & $.42^{*}$ & $.37^{*}$ \\
\hline Food security & & 1 & $.66^{*}$ & $.65^{*}$ & $.78^{*}$ & $.39^{*}$ & -.02 & $.34^{*}$ & $.30^{*}$ & $.39^{*}$ \\
\hline Housing condition sufficiency & & & 1 & $.69^{*}$ & $.60^{*}$ & $.43^{*}$ & -.06 & $.32^{*}$ & $.39^{*}$ & $.35^{*}$ \\
\hline Healthcare access & & & & 1 & $.72^{*}$ & $.53^{*}$ & -.19 & .19 & $.28^{*}$ & $.39^{*}$ \\
\hline Transportation access & & & & & 1 & $.41^{*}$ & .01 & $.40^{*}$ & $.31^{*}$ & $.37^{*}$ \\
\hline Neighborhood safety & & & & & & 1 & .06 & $.48^{*}$ & $.31^{*}$ & $.28^{*}$ \\
\hline Education opportunities & & & & & & & 1 & .24 & -.11 & -.05 \\
\hline Employer respect & & & & & & & & 1 & $.53^{*}$ & $.53^{*}$ \\
\hline No discrimination of respondent & & & & & & & & & 1 & $.93^{*}$ \\
\hline $\begin{array}{l}\text { No discrimination of household } \\
\text { member/s }\end{array}$ & & & & & & & & & & 1 \\
\hline
\end{tabular}

Asterisk (*) indicates association is statistically significant at .001 level using chi-square test. 
Table 3 Summary of basic needs met by characteristics of respondents $(\mathrm{N}=\mathbf{9 7 8}$ ), Ventura County, California, 2013

\begin{tabular}{|c|c|c|c|c|c|c|c|c|c|c|c|}
\hline & \multicolumn{10}{|c|}{ Proportions reporting basic need met } & \multirow[b]{2}{*}{$\begin{array}{l}\text { Mean total } \\
\text { number of need } \\
\text { met }( \pm \text { SD) }\end{array}$} \\
\hline & $\begin{array}{l}\text { Employment } \\
\text { opportunities }\end{array}$ & $\begin{array}{l}\text { Food } \\
\text { security }\end{array}$ & $\begin{array}{l}\text { Housing situation } \\
\text { sufficiency }\end{array}$ & $\begin{array}{l}\text { Healthcare } \\
\text { access }\end{array}$ & $\begin{array}{l}\text { Transportation } \\
\text { access }\end{array}$ & $\begin{array}{l}\text { Neighborhood } \\
\text { safety }\end{array}$ & $\begin{array}{l}\text { Education } \\
\text { opportunities }\end{array}$ & $\begin{array}{l}\text { Employer } \\
\text { respect }\end{array}$ & $\begin{array}{l}\text { No discrimination } \\
\text { against respondent }\end{array}$ & $\begin{array}{l}\text { No discrimination } \\
\text { against household } \\
\text { member/s }\end{array}$ & \\
\hline $\begin{array}{l}\text { Male respondent } \\
(n=154)\end{array}$ & $.39^{* * *}$ & $.49^{*}$ & .53 & .58 & $.55^{* * *}$ & .43 & $.66^{* *}$ & .82 & $.73^{*}$ & .70 & $5.8( \pm 2.6)^{*}$ \\
\hline $\begin{array}{l}\text { Female respondent } \\
(n=834)\end{array}$ & .24 & .40 & .51 & .51 & .38 & .50 & .53 & .83 & .64 & .67 & $5.3( \pm 2.5)$ \\
\hline $\begin{array}{l}\text { Married/living as } \\
(\mathrm{n}=847)\end{array}$ & $.27^{* *}$ & .42 & .52 & $.59^{* * *}$ & $.42^{*}$ & .50 & $.54^{*}$ & $.84^{*}$ & .65 & .68 & $5.4( \pm 2.5)^{*}$ \\
\hline Single $(n=123)$ & .16 & .34 & .46 & .40 & .30 & .42 & .66 & .76 & .69 & .66 & $4.8( \pm 2.3)$ \\
\hline $\begin{array}{l}\text { Spent time in } \\
\text { another city } \\
(\mathrm{n}=144)\end{array}$ & .29 & .43 & .55 & $.67^{* *}$ & .47 & .50 & .52 & .83 & .72 & .67 & $5.7( \pm 2.6)$ \\
\hline Did not $(n=817)$ & .26 & .41 & .51 & .55 & .40 & .49 & .56 & .82 & .64 & .68 & $5.3( \pm 2.5)$ \\
\hline $\begin{array}{l}\text { Speaks Spanish } \\
(n=745)\end{array}$ & .27 & .40 & $.47^{* * *}$ & $.51 * * *$ & .40 & .50 & $.61 * * *$ & $.84^{*}$ & .66 & .68 & $5.4( \pm 2.5)$ \\
\hline $\begin{array}{l}\text { Does not speak } \\
\text { Spanish }(n=227)\end{array}$ & .22 & .44 & .65 & .74 & .42 & .46 & .36 & .77 & .64 & .66 & $5.4( \pm 2.4)$ \\
\hline $\begin{array}{l}\text { Age }<30 \text { years } \\
(n=473)\end{array}$ & $.30^{* *}$ & $.46^{* *}$ & $.57^{* * *}$ & $.60^{*}$ & $.44^{*}$ & $.53^{*}$ & .58 & .83 & $.71^{* *}$ & .71 & $5.7( \pm 2.4)^{* * *}$ \\
\hline $\begin{array}{l}\text { Age } \geq 30 \text { years } \\
(n=505)\end{array}$ & .22 & .37 & .45 & .52 & .37 & .46 & .53 & .83 & .61 & .65 & $5.0( \pm 2.5)$ \\
\hline $\begin{array}{l}\text { Household } \\
\text { members }<5 \\
(n=436)\end{array}$ & .28 & $.47^{* *}$ & $.59 * * *$ & $.62^{* *}$ & .44 & .51 & .56 & .82 & $.71^{* *}$ & $.73^{* *}$ & $5.7( \pm 2.5)^{* * * *}$ \\
\hline $\begin{array}{l}\text { Household } \\
\text { members } \geq 5 \\
(n=492)\end{array}$ & .24 & .37 & .44 & .53 & .38 & .47 & .55 & .83 & .62 & .64 & $5.1( \pm 2.4)$ \\
\hline $\begin{array}{l}\text { Used }>6 \text { services } \\
(n=490)\end{array}$ & $.31^{* *}$ & $.45^{*}$ & .51 & $.61 * *$ & $.46^{* *}$ & .48 & .53 & .83 & .65 & .69 & $5.5( \pm 2.6)^{*}$ \\
\hline $\begin{array}{l}\text { Used } \leq 6 \text { services } \\
(n=499)\end{array}$ & .22 & .37 & .51 & .52 & .35 & .50 & .57 & .82 & .66 & .66 & $5.2( \pm 2.4)$ \\
\hline
\end{tabular}

${ }^{*}$ significant at $\mathrm{p} \leq .05 ;{ }^{* *}$ significant at $\mathrm{p} \leq .01 ;{ }^{* *}$ significant at $\mathrm{p} \leq .001$ (chi-square tests for proportions and $\mathrm{t}$ tests comparing mean total number of needs met) 
Table 4 Adjusted odds ratios from multivariate logistic regression models predicting basic need items among respondents ( $\mathrm{N}=978$ ), Ventura County, California, 2013

\begin{tabular}{|c|c|c|c|c|c|c|c|c|c|c|}
\hline & \multicolumn{10}{|l|}{ Outcomes } \\
\hline & $\begin{array}{l}\text { Employment } \\
\text { opportunities }\end{array}$ & $\begin{array}{l}\text { Food } \\
\text { security }\end{array}$ & $\begin{array}{l}\text { Housing situation } \\
\text { sufficiency }\end{array}$ & $\begin{array}{l}\text { Healthcare } \\
\text { access }\end{array}$ & $\begin{array}{l}\text { Transportation } \\
\text { access }\end{array}$ & $\begin{array}{l}\text { Neighborhood } \\
\text { safety }\end{array}$ & $\begin{array}{l}\text { Education } \\
\text { opportunities }\end{array}$ & $\begin{array}{l}\text { Employer } \\
\text { respect }\end{array}$ & $\begin{array}{l}\text { No discrimination } \\
\text { against respondent }\end{array}$ & $\begin{array}{l}\text { No discrimination against } \\
\text { household member/s }\end{array}$ \\
\hline Male (Ref: female) & $2.0^{* * *}(1.3-3.0)$ & $1.6^{*}(1.1-2.4)$ & $1.1(0.8-1.7)$ & $0.8(0.6-1.2)$ & $2.1^{* * *}(1.4-3.1)$ & $0.7(0.5-1.0)$ & $1.6^{*}(1.0-2.3)$ & $0.8(0.5-1.4)$ & $1.4(0.9-2.1)$ & $1.1(0.7-1.6)$ \\
\hline $\begin{array}{l}\text { Married/living as } \\
\text { married (Ref: single) }\end{array}$ & $1.9^{*}(1.1-3.4)$ & $1.5(0.9-2.3)$ & $1.6^{*}(1.1-2.5)$ & $2.1^{* * *}(1.4-3.3)$ & $1.8^{*}(1.1-2.8)$ & $1.5(1.0-2.2)$ & $0.6^{*}(0.4-0.9)$ & $1.8^{*}(1.1-3.0)$ & $0.7(0.5-1.2)$ & $1.1(0.7-1.8)$ \\
\hline $\begin{array}{l}\text { Spent time in another } \\
\text { city (Ref: did not) }\end{array}$ & $1.1(0.7-1.7)$ & $1.0(0.7-1.5)$ & $1.0(0.7-1.5)$ & $1.7^{*}(1.1-2.5)$ & $1.4(0.9-2.0)$ & $1.0(0.7-1.4)$ & $0.7(0.5-1.0)$ & $1.1(0.6-1.7)$ & $1.4(0.9-2.2)$ & $1.0(0.6-1.4)$ \\
\hline $\begin{array}{l}\text { Speaks Spanish } \\
\text { (Ref: does not) }\end{array}$ & $1.1(0.8-1.7)$ & $0.8(0.6-1.1)$ & $0.4^{* * *}(0.3-0.6)$ & $0.4^{* * *}(0.3-0.6)$ & $0.9(0.7-1.3)$ & $1.2(0.9-1.7)$ & $2.9^{* * *}(2.1-4.0)$ & $1.6^{*}(1.1-2.4)$ & $1.1(0.8-1.5)$ & $1.1(0.8-1.5)$ \\
\hline $\begin{array}{l}\text { Age }<30 \text { years } \\
\text { (Ref: } \geq 30 \text { years) }\end{array}$ & $1.4(1.0-1.9)$ & $1.3(1.0-1.7)$ & $1.4^{*}(1.0-1.8)$ & $1.3(0.9-1.7)$ & $1.2(0.9-1.6)$ & $1.2(0.9-1.6)$ & $1.3(1.0-1.7)$ & $0.9(0.6-1.3)$ & $1.5^{* *}(1.1-2.0)$ & $1.2(0.9-1.6)$ \\
\hline $\begin{array}{l}\text { Household size }<5 \\
\text { (Ref: } \geq 5 \text { ) }\end{array}$ & $1.3(0.9-1.8)$ & $1.6^{* *}(1.2-2.1)$ & $1.8^{* * *}(1.3-2.4)$ & $1.6^{* *}(1.2-2.1)$ & $1.4^{*}(1.1-1.9)$ & $1.2(0.9-1.6)$ & $1.0(0.7-1.4)$ & $1.0(0.7-1.5)$ & $1.3(0.9-1.7)$ & $1.6^{* *}(1.2-2.2)$ \\
\hline $\begin{array}{l}\text { Used }>6 \text { services } \\
\text { (Ref: } \leq 6)\end{array}$ & $1.8^{* * *}(1.3-2.5)$ & $1.5^{* *}(1.1-2.0)$ & $1.1(0.8-1.5)$ & $1.5^{* *}(1.2-2.1)$ & $1.8^{* * *}(1.3-2.4)$ & $0.9(0.7-1.2)$ & $1.0(0.7-1.3)$ & $1.0(0.7-1.4)$ & $1.1(0.8-1.4)$ & $1.2(0.9-1.7)$ \\
\hline
\end{tabular}

All odds ratios are adjusted for all other predictors in the model.

${ }^{*}$ significant at $\mathrm{p} \leq .05$; ** significant at $\mathrm{p} \leq .01$; ***significant at $\mathrm{p} \leq .001>$ 
from larger households. Respondents who had used more than 6 out of 12 local agencies and/or health service providers were more likely to report sufficient employment opportunities, food security and access to healthcare and transportation than respondents who had used fewer service providers.

\section{Discussion}

We conducted one of the largest needs assessments among indigenous people from Mexico who have settled in the U.S. Through a community-based participatory research process that included an established and trusted community organization and indigenous promotoras, we were able to conduct almost 1,000 surveys in two indigenous languages and in Spanish in an immigrant community that is largely undocumented and has low levels of income and education. Our method for consistent administration of a needs assessment in a language that does not have a written form might be useful for conducting assessments in other areas of interest and for other indigenous groups that lack a written language. However, we have to acknowledge that this process can also lead to errors if the questions are not asked exactly as written in Spanish or if the responses are incorrectly recorded in the Spanish language survey.

Confirming findings from surveys conducted among much smaller samples of indigenous farm workers in Oregon [10] and California [16,17], our data, collected in the Mixtec and Zapotec community in Ventura County, California, show that many basic needs such as food security, housing and access to health care are not met. These basic needs, which are human rights and social determinants of health, are the foundation of public health efforts [14]. Our data suggest that the majority of children have access to health care, but this access often comes at the price of waiting at the emergency room for many hours to be seen (personal communication, Sandra Young, 4/27/14).

A farm worker study conducted in Fresno, California that focused on food security found large seasonal differences: only $24 \%$ of Mixteco-speaking respondents reported sufficient food in winter but $100 \%$ reported sufficient food in summer. The researchers attribute this big difference to the fact that the sample recruited in winter included more women with families and an average of 33 hours of work per week, while almost half the respondents in the summer were unaccompanied men that worked on average 60 hours per week [17]. Our study was conducted during the harvest season, and results might have been quite different had we conducted the survey in a season when there are fewer employment opportunities.

Some of the results were unexpected: Although discrimination is described as an important issue among migrant farm workers [10], the majority of adults in our sample reported that they were treated with respect by employers and that nobody in their household had experienced discrimination or bullying. We found that different demographic characteristics were associated with different needs, sometimes in unexpected directions. For example, we had expected that respondents of Spanish-speaking households would have more of their basic needs covered than respondents of non-Spanish-speaking households. While respondents of Spanish-speaking households were more likely to report being treated with respect by employer and having education opportunities than respondents of non-Spanish speaking households, respondents of non-Spanish speaking households were more likely to report access to health care and sufficient housing than respondents of Spanish-speaking households. One reason for this unexpected finding may be lower expectations among non-Spanish speaking community members regarding health care access and housing, rather than better coverage of health care needs.

Per recommendation of the Community Advisory Board, we did not assess immigration status, income or educational level among participants in our study. Another survey that included 60 Mixtec farm workers in Fresno County, California found that $98 \%$ of respondents were undocumented, $90 \%$ had an education of 6 th grade or less and the mean monthly income per person ranged from $\$ 271$ in winter to $\$ 1,927$ in summer [17]. Both our and the Fresno study used similar recruitment methods, and based on personal communications with MICOP staff, our sample most likely also included a substantial proportion of undocumented farm workers. In addition to language and other barriers, being undocumented is a major obstacle to accessing health care and social services [18]. Our finding of moderate to strong correlations of basic needs regarding food security, housing, transportation and access to health care suggest that many respondents have multiple needs that have to be addressed simultaneously; however, undocumented farm workers will be extremely hesitant to utilize health and social services (personal communication, Sandra Young, 4/27/14).

\section{Limitations}

All data are based on self-report. The survey had to be short to minimize respondent burden - therefore, the number of questions was limited and questions focused on expected areas of unmet basic needs; we did not assess assets such as the strong sense of community in these Mixtec and Zapotec groups. The majority of respondents were female and males were underrepresented; although many questions assessed household needs, females could have been more forthcoming than males to report unmet needs, which could explain some of the gender 
differences we found. We interviewed a convenience sample, although given the reported excellent participation rate, the large number of participants and the recruitment at several different locations in the greater Oxnard area, we believe that the survey provided a good snapshot of the basic needs of indigenous farm workers in Ventura County.

\section{Conclusions}

Our survey documents that the Mixtec and Zapotec community in Ventura County experiences major problems in many basic needs. Having local data will draw attention to this community that has often been described as "invisible" $[1,19,20]$. MICOP has begun the process of sharing information from this survey with local health care providers. However, it will require many different resources and services to address the many needs of this community and to overcome longstanding inequities that are experienced by immigrant farm workers $[2,18]$. Our findings will guide future programming of MICOP and will serve as a baseline to evaluate the impact of services to improve the health conditions in this community. Both the community and the academic partners of this collaboration have agreed to continue research in this indigenous farmworker community with a focus on increasing the capacity of MICOP and indigenous promotoras to engage in health promotion.

\section{Competing interest}

The authors declare that they have no competing interests.

\begin{abstract}
Authors' contributions
AEM and SY conceived of the study, and participated in its design and coordination. AEM drafted the manuscript and received critical feedback from all other authors. SY oversaw implementation of study activities. CMC directed the statistical analysis. RRV conducted promotora trainings. RCT conducted data management and analysis. All authors read and approved the final manuscript.
\end{abstract}

\section{Acknowledgments}

This research was supported by funds from the California Breast Cancer Research Grants Program Office of the University of California, Grant Number 18AB-1400. Additional support was provided by the UCLA Kaiser Permanente Center for Health Equity, by the NIH/National Center for Advancing Translational Science (NCATS) UCLA CTSI Grant Number UL1TR000124 and by the CDU/UCLA Cancer Center Partnership to Eliminate Cancer Health Disparities, $\mathrm{NIH/NCI}$ Grant\# U54-CA-143931.

\section{Author details \\ ${ }^{1}$ Fielding School of Public Health and Jonsson Comprehensive Cancer Center, UCLA Kaiser Permanente Center for Health Equity, University of California, 650 Charles Young Drive South, A2-125 CHS, Box 956900, Los Angeles, CA 90095-6900, USA. ${ }^{2}$ Mixteco/Indigena Community Organizing Project, PO Box 20543, Oxnard, CA 93034, USA.}

Received: 1 August 2014 Accepted: 21 January 2015

Published online: 03 February 2015

\section{References}

1. Mines R, Nichols S, Runsten D. California's indigenous farmworkers. 2010.

2. Ramirez SM, Villarejo D. Poverty, housing, and the rural slum: policies and the production of inequities, past and present. Am J Public Health. 2012;102(9):1664-75.
3. Escobedo J, Chavira I, Martinez L, Velasco X, Escandon C, Cabral J. Diabetes and other glucose metabolism abnormalities in Mexican Zapotec and Mixe Indians. Diabet Med. 2010;27(4):412-6.

4. Goodman D, Fraga MA, Brodine S, Ibarra MD, Garfein RS. Prevalence of diabetes and metabolic syndrome in a migrant Mixtec population, Baja California, Mexico. J Immigr Minor Health. 2013;15(1):93-100.

5. Malina RM, Reyes ME, Tan SK, Little BB. Physical activity in youth from a subsistence agriculture community in the Valley of Oaxaca, southern Mexico. Appl Physiol Nutr Metab. 2008;33(4):819-30.

6. Schulz LO, Weidensee RC. Glucose tolerance and physical activity in a Mexican indigenous population. Diabetes Care. 1995;18(9):1274-6.

7. Farquhar S, de Jesus Gonzalez C, Hall J, Samples J, Ventura S, Sanchez V, et al. Recruiting and retaining indigenous farmworker participants. J Immigr Minor Health. 2014;16(5):1011-5.

8. Espinoza R, Martinez I, Levin M, Rodriguez A, Chan T, Goldenberg S, et al. Cultural perceptions and negotiations surrounding sexual and reproductive health among migrant and non-migrant indigenous Mexican women from Yucatan, Mexico. J Immigr Minor Health. 2014;16(3):356-64.

9. McCauley L, Runkle JD, Samples J, Williams B, Muniz JF, Semple M, et al. Oregon indigenous farmworkers: results of promotor intervention on pesticide knowledge and organophosphate metabolite levels. J Occup Environ Med. 2013;55(10):1164-70.

10. Farquhar S, Shadbeh N, Samples J, Ventura S, Goff N. Occupational conditions and well-being of indigenous farmworkers. Am J Public Health. 2008;98(11):1956-9.

11. Maxwell AE, Young S, Rabelo Vega R, Herrmann AK, See C, Glenn BA, et al. Training Mixtec promotores to assess health concerns in their community: a CBPR pilot study. J Immigr Minor Health. 2014;16(2):310-3.

12. Minkler M, Lee PT, Tom A, Chang C, Morales A, Liu SS, et al. Using community-based participatory research to design and initiate a study on immigrant worker health and safety in San Francisco's Chinatown restaurants. Am J Ind Med. 2010;53(4):361-71.

13. Israel BA, Schulz AJ, Parker EA, Becker AB. Community-based participatory research: policy recommendations for promoting a partnership approach in health research. Educ Health (Abingdon). 2001;14(2):182-97.

14. Frieden TR. A framework for public health action: the health impact pyramid. Am J Public Health. 2010;100(4):590-5.

15. Knoke D, Bohrnstedt GW, Mee AP. Statistics for social data analysis. 4th ed. Itasca, IL: F.E. Peacock Publishers; 2002.

16. Salgado H, Haviland I, Hernandez M, Lozano D, Osoria R, Keyes D, et al. Perceived discrimination and religiosity as potential mediating factors between migration and depressive symptoms: a transnational study of an indigenous mayan population. J Immigr Minor Health. 2014;16(3):340-7.

17. Wirth C, Strochlic R, Getz C. Hunger in the fields: food insecurity among farmworkers in Fresno County: California Institute for Rural Studies. 2007.

18. McGuire SS. Agency, initiative, and obstacles to health among indigenous immigrant women from Oaxaca, Mexico. Home Health Care Manage Pract. 2006;18(5):370-7.

19. Alderete E, Vega WA, Kolody B, Aguilar-Gaxiola S. Lifetime prevalence of and risk factors for psychiatric disorders among Mexican migrant farmworkers in California. Am J Public Health. 2000;90(4):608-14.

20. Lee J, Donlan W, Cardoso EE, Paz JJ. Cultural and social determinants of health among indigenous Mexican migrants in the United States. Soc Work Pub Health. 2013;28(6):607-18.

\section{Submit your next manuscript to BioMed Central and take full advantage of:}

- Convenient online submission

- Thorough peer review

- No space constraints or color figure charges

- Immediate publication on acceptance

- Inclusion in PubMed, CAS, Scopus and Google Scholar

- Research which is freely available for redistribution 